\title{
A ESTRUTURA RETÓRICA DO VERBETE SPINOZA
}

\author{
Marilena Chaui* \\ mchaui@ajato.com.br
}

RESUMO Propomos uma análise do verbete "Spinoza" do Dictionnaire Historique et Critique salientando a estrutura retórica do texto, em cujo centro se encontra a nova figura do ateu, construída por Bayle, o ateu especulativo ou "o ateu de sistema".

Palavras-chave ateu, ateísmo, Espinosa, retórica

ABSTRACT The paper presents a study of the rhetorical framework of the article "Spinoza" in Bayle's Dictionnaire Historique et Critique and the new image of the atheist as athée de système.

Key-words atheism, atheist, Spinoza, rhetorics

\section{Bayle e o nascimento da tradição interpretativa do espinosismo}

Para os estudiosos dafilosofia espinosana, o verbete Spinoza do Dictionnaire é de grande relevância histórica, pois, com Bayle, nasce propriamente a tradição interpretativa do espinosismo. São dele idéias, imagens e sugestões que iriam alimentar, durante os séculos vindouros, as sucessivas leituras da obra e, mais freqüentemente, as substituíram, o verbete sendo mais lido do que Espinosa. Por ser essencialmente um publicista, divulgador e difusor

* Universidade de São Paulo. Recebido em 07/08/2009 e aceito em 14/10/2009. 
das opiniões de sua época na perspectiva do protestantismo tolerante, Bayle evita deliberadamente opor à filosofia de Espinosa uma outra, como fizeram os críticos que o antecederam. Pretende colocar Espinosa contra si mesmo para que se destrua. Com seu verbete, institui um campo de generalidades no qual ficou esculpida em baixo-relevo a imagem do espinosismo que seria gravada como um selo nos comentários, interpretações e retomadas que a obra espinosana iria suscitar na fieira dos tempos.

Melhor do que qualquer de seus contemporâneos, Bayle expõe o malestar causado pela filosofia de Espinosa, que parece exigir dos leitores plena adesão ou obrigá-los à total repulsa. Ao mesmo tempo, em decorrência do papel por ele atribuído ao "ateu virtuoso", introduz a tendência contínua e tenaz da fortuna crítica do espinosismo, isto é, o uso da biografia de Espinosa tanto como peça de acusação quanto como álibi para salvar-lhe a vida, condenando-lhe a obra. Inaugura as principais vertentes da interpretação da obra de Espinosa ao oferecer um conjunto de traços articulados que viriam a se desarticular, posteriormente, nas interpretações de seus sucessores: dele vem a imagem do Espinosa cabalista, que Wachter e Leibniz iriam explorar; a do oriental, que, primeiro, Malebranche e Leibniz e, depois, Hegel não cessariam de enfatizar, vindo a ser retomada por intérpretes nossos contemporâneos; a do materialista, que iria receber a boa acolhida dos ilustrados franceses, a repulsa dos idealistas alemães e o interesse de Feuerbach, Marx e Engels, passando aos marxistas, até chegar a nossos dias; a do místico entusiasta, que repugnaria Kant, mas iria apaixonar os românticos; a do herdeiro de Duns Scotus, que será desenvolvida por nossos contemporâneos.

Nele, melhor do que em todos os outros, consolida-se a imagem do perigo espinosista, isto é, de uma razão que não conhece limites, cuja hybris a faz descambar no paradoxo e na incoerência. Essa imagem que, em Bayle e na sua posteridade imediata, cristaliza-se na figura do "ateu de sistema", irá, mais adiante, com a laicização do augustinismo, do calvinismo e do jansenismo (laicização que traduz o tema do fatalismo metafísico e da predestinação teológica para o tema filosófico-científico do determinismo), levar ao aparecimento do "problema do espinosismo", isto é, a impossibilidade de uma ética da liberdade numa filosofia que expulsa a finalidade e afirma a necessidade absoluta, problema enfaticamente posto por Jacobi na "querela do panteísmo", retomado com obstinação por Kant e jamais abandonado depois dele. De Bayle vem ainda a imagem da insensatez de Espinosa, como conseqüência do exagero racionalista de um cartesiano oriental e entusiasta, imagem que, por seu turno, levará à do pensador contraditório, que iria alimentar inumeráveis comentários da obra. 


\section{Ateísmo prático ou o ateu virtuoso}

Para o leitor de Pensamentos Diversos sobre o Cometa, a atitude de Bayle, no Dicionário, é desconcertante. De fato, no texto de 1683, partindo do martírio de Vanini, da consideração do pensamento dos libertinos e da vida exemplar de Espinosa, Bayle acompanhava Plutarco para quem o ateísmo não é pernicioso para a vida civil, porque daninha para ela é a superstição, verdadeira causa do ateísmo, pois:

\footnotetext{
'os primeiros que abraçaram o ateísmo não o fizeram por terem alguma coisa a dizer sobre os céus, os astros, as estações, as revoluções do sol (...) nem por haverem notado alguma desordem ou defeito no alimento dos animais ou na produção dos frutos. Nada disso. Foi a superstição a causa: suas ações estranhas, suas paixões ridículas, suas palavras, seus movimentos, suas feitiçarias e encantamentos (...) os ultrajes feitos a si mesma nos templos, tudo isso levou alguns a dizer que mais valeria aos homens não ter Deus algum do que vê-los aprovar tais coisas' (...) A finalidade de Plutarco é fazer ver que a superstição é pior do que ateísmo. ${ }^{1}$
}

A crença verdadeira resume-se a poucos dogmas: há um Deus criador e providencial, há vida futura e julgamento das ações humanas, os homens precisam da graça divina, dom do Espírito Santo, e da redenção, dom do Filho. Como os membros da Royal Society, Bayle afirma a existência dos milagres e por isso mesmo sublinha sua excepcionalidade, afastando-os dos fatos naturais cotidianos que, se tidos por milagrosos, indicam mais a ignorância e a superstição do vulgo do que o poder divino.

$\mathrm{O}$ ateísmo pode ser eficazmente combatido pela percepção de que a Natureza é prodigiosamente bem ordenada e que essa ordem lhe deve ter sido imposta por uma inteligência e vontade superiores. Pode-se também combatê-lo pela autoridade dos políticos, pois podemos satisfazer às nossas dúvidas sem recorrer à razão nem à experiência, recorrendo a algo "mais doce, pacífico e apaziguante", isto é, à autoridade do soberano, que declara qual é a verdadeira religião, que obedecê-la é a verdadeira piedade e que a verdadeira virtude está no amor à pátria e no temor aos castigos. Outra via eficaz no combate ao ateísmo é a autoridade dos sacerdotes, únicos investidos no poder de interpretar augúrios, presságios, profecias e revelações e impô-las ao povo, castigando os que se opuserem ao sentido apresentado. Enfim, não menos eficaz nesse combate são as ações dos demônios porque não desejam a existência de ateus, sobre os quais nada podem, e preferem a dos devotos, competindo com 
Deus pela posse de suas almas. Ordem natural, ordem institucional e ordem sobrenatural são, pois instrumentos suficientes para combater o ateísmo.

A idolatria ou superstição é pior do que o ateísmo porque é pior uma crença que atribui imperfeições a Deus do que a mera negação de Sua existência, pois uma crença desse tipo favorece brutalidades, extravagâncias, crimes e paixões poluidoras, levando a impiedade maior do que a daquele que nada atribui a Deus porque Lhe nega o ser. O conhecimento que o idólatra possui de Deus só serve para tornar seus crimes mais atrozes, pois o ateu desconhece a vontade de Deus, mas o idólatra a conhece e, portanto, seus crimes não podem ser imputados à ignorância, mas à malícia. Não se deve esquecer, ainda, que é mais difícil converter um idólatra do que um ateu, pois ao crer em falsos princípios e praticar falsas cerimônias, seu espírito fica preenchido e convencido de que está na verdadeira religião e nada o fará abandoná-la, senão com enorme dificuldade. Finalmente, a idolatria é pior do que o ateísmo porque a desordem e a obstinação nas disposições do entendimento e do coração dos idólatras são maiores do que nos ateus, pois as infâmias que os primeiros atribuem a Deus são piores do que a "horrível cegueira" e a "prodigiosa ignorância" dos segundos.

Bayle coloca esse conjunto de teses a serviço de um argumento preciso, ao término do qual surgirá a figura, até então impensável, do "ateu virtuoso". Com efeito, as teses aduzidas por Bayle levam, paulatinamente, à idéia de que o ateísmo não é natural - naturalmente os homens tendem a crer numa divindade ordenadora da Natureza -, mas resulta da crítica da idolatria e da superstição, que destroem tanto a religião natural quanto o cristianismo ou religião revelada. A malícia e o desregramento em que vivem os supersticiosos permitem inferir que essa crítica não é feita por aqueles que se deliciam com uma vida de crimes e deboches, nem por aqueles que se satisfazem com a boa mesa, a boa cama, a fama, a riqueza e a glória porque esses não têm tempo nem o menor interesse em discutir as divergências entre peripatéticos e platônicos, acadêmicos e cartesianos. São, portanto, os homens de bem que fazem a crítica e por ela são arrastados ao ateísmo, à vista do escândalo da idolatria e da superstição.

Apanhando um fio lançado pelos libertinos eruditos, Bayle determina o campo no qual o ateísmo pode ser compreendido: o dos costumes ou das convenções religiosas, políticas e teológicas, e o dos temperamentos ou caracteres. Indaga ele: por que vemos as mesmas paixões e os mesmos vícios em todos os homens, sejam eles judeus, cristãos, pagãos ou maometanos? Turco ou persa, indu ou tártaro, nobre ou plebeu, dessemelhantes em tantos 
costumes, porque são semelhantes em tantas paixões? E responde que isso decorre apenas

de que o verdadeiro princípio das ações do homem não é outro senão o temperamento, a inclinação natural para o prazer, o gosto por certos objetos, o desejo de agradar alguém, ou alguma outra disposição que resulta do fundo de nossa natureza, seja qual for o país em que se nasça e sejam quais forem os conhecimentos com que nos encham o espírito?

Costumes, leis, religiões, cerimônias nascem desse fundo e da necessidade de dirigi-lo para que os homens não sejam inteiramente funestos uns aos outros. Nessa perspectiva, não há porque conservar a idéia de maldade natural dos ateus, nem que sejam mais viciosos ou mais criminosos do que os outros. A história e a experiência ensinam que houve e há inúmeros ateus virtuosos e isso "não é mais estranho do que um cristão que pratique todo tipo de crime", pois se vemos "essa espécie de monstro todos os dias, porque acreditar que a outra seria impossível?". Donde a conclusão de que "o ateísmo não conduz necessariamente à corrupção dos costumes" e que a devoção religiosa tanto quanto a descrença dependam menos do conhecimento da existência de Deus e muito mais do tipo de temperamento e do costume que sobre ele atua:

Do fato de haver ateus que, moralmente falando, têm boas inclinações, é fácil concluir que o ateísmo não é uma causa necessária de vida malvada, mas somente uma causa por acidente, ou uma causa que não produz a corrupção dos costumes, senão naqueles que tem forte inclinação para o mal para cair no deboche mesmo sem isso. ${ }^{3}$

A partir dessa conclusão, nada impede conceber a possibilidade de uma sociedade atéia, "mesmo que disso não tenhamos Anais e Histórias". Bayle não julga, portanto, escandalosas ou descabidas as idéias de La Mothe Le Vayer, ainda que contrárias às mais caras teses cristãs, quanto à possibilidade de uma república atéia, bastando para tanto observar que

uma sociedade de ateus praticaria ações civis e morais tanto quanto as praticam outras sociedades, desde que faça punir severamente os crimes e que atribua honra ou infâmia a certas coisas. ${ }^{4}$

Aliás, é possível imaginar que, nessa república, a virtude seja mais prezada do que nas sociedades religiosas porque, não crendo na Providência, nem na 
imortalidade da alma e na remuneração após a morte, seus membros só podem crer neles mesmos e nas leis que promulgarem, respeitando-as como condição única de suas vidas e da felicidade possível.

As idéias desenvolvidas por Bayle nos Pensamentos Diversos não desaparecem inteiramente no Dicionário. Justamente porque as noções de temperamento e costume são centrais na elaboração bayleana do ateísmo, no verbete Spinoza a biografia de Espinosa exibe seu temperamento e o apresenta como homem virtuoso, por inclinação e por costume. Também não desaparece a afirmação de que obediência e medo políticos vão de par com a religiosidade supersticiosa e a concordância com "muitos" que disseram haver sido a religião inventada para obter obediência medrosa dos crentes e súditos. Esses "muitos", por negarem a imortalidade da alma e a divina providência, são aqueles que mais prezam a verdadeira virtude e sua utilidade social. $\mathrm{O}$ Dicionário conserva, portanto, a idéia de "ateu virtuoso". A novidade trazida pelo verbete Spinoza é outra por assentar-se numa outra figura de Espinosa: a do "ateu de sistema", idéia espantosa porque nem mesmo os defensores do ateísmo virtuoso admitiram a possibilidade do ateísmo especulativo. Com efeito, por motivos diferentes, Bacon, Descartes, Arnauld, Malebranche e Leibniz consideram o ateu uma figura aquém da razão e por isso um ateu especulativo é uma contradição nos termos. Um "ateu de teoria", como diz o século, é impossível. Para Bayle, no entanto, a existência do sistema espinosista aparece como a finalização do projeto insensato da razão moderna: levado às últimas conseqüências, o racionalismo só pode ser ateísmo especulativo.

Duas idéias permanecem constantes no pensamento de Bayle, desde Pensées Diverses até o Dictionnaire: a primeira é que as objeções filosóficas à fé são legítimas e mais claras do que as respostas dos teólogos porque a razão é potente para objetar, mas os mistérios da fé são incompreensíveis e dependem da autoridade de Deus; a segunda é que preciso ter a religião no coração e não no espírito porque daquilo que está no espírito, a razão pode ser juiz, porém não tem competência para julgar "o que se passa no coração de outrem". A razão é publicidade; o coração, interioridade.

É impossível, para o homem, realizar a síntese entre seu saber e sua crença. Por isso, na mesma medida em que à consciência religiosa repugnam as tentativas dos teólogos para tornar racional a fé, também à consciência cética repugna a tentativa oposta, isto é, o ateísmo, que busca a superioridade da razão sobre a fé. Assim, não há, em Bayle, paradoxo entre a tolerância para com o "ateu virtuoso" e a intolerância para com o "ateu de sistema". A filosofia de Espinosa é combatida enquanto sistema racional do ateísmo. Porque, no Dicionário, o combate se trava contra o sistema e sua pretensão à 
racionalidade, a argumentação de Bayle (em perfeitamente consonância com os preceitos da retórica judiciária) articula a cada tese considerada racionalmente absurda uma proposição tida por religiosamente ímpia, a fim de alcançar o alvo preciso, isto é, demonstrar que a filosofia de Espinosa contraria a razão, a experiência e os bons sentimentos.

O ateísmo, predisposição universal de certos temperamentos que combatem a idolatria e a superstição, metafisicamente afirma como dogmas: identidade entre Deus e universo, eternidade e necessidade da Natureza, inexistência de entes singulares ou de indivíduos distintos da substância divina. O ateísmo sistemático ou especulativo é a predisposição atéia transformada em teoria matematicamente demonstrada. Em suma, a virtude atéia não é necessariamente correlato de boa metafísica.

\section{A nova figura do ateísmo}

O verbete Spinoza cobre um campo vasto de referências que balizam a acusação de ateísmo. Se é verdade que, no caso específico de Espinosa, as principais referências são, na metafísica, a unicidade substancial e o mecanicismo; na política, o direito natural e civil como potências despojadas da normatividade exigida pela idéia de justiça; e, na moral, a teoria dinâmica do conatus, que elimina causas finais e livre-arbítrio, não é menos verdade que essas teses são apresentadas no interior de uma moldura formada pela história do ateísmo como predisposição do espírito humano toda vez que depara com a superstição. Todavia, há algo mais profundo que subjaz ao texto de Bayle, isto é, a mudança histórica da imagem do ateísmo.

Entre o final do século XVI e o início do século XVII, o termo ateu é empregado para referir-se a duas atitudes principais: ao anti-clericalismo e anti-sacramentalismo plebeus, tanto na tradição da blasfêmia e irreverência populares, quanto nas seitas espirituais; e ao ceticismo dos empiristas, que não admitem que a experiência possa oferecer o conhecimento das verdades propostas pela fé, atribuem origem política às religiões e ostentam, pelo menos publicamente, o fideísmo, estando mais interessados em denunciar a superstição e os preconceitos do que em discutir provas da existência ou inexistência de Deus.

Quando Bacon escreve, no início do século, oferece quatro causas para o ateísmo: as divisões religiosas, pois quando são poucas cada partido se esmera no zelo para provar sua superioridade, mas, quando muitas, perdem todas o valor, ao mesmo tempo em cada uma delas finge excesso de santidade e descamba na exterioridade farisaica; o anti-clericalismo, provocado pelos 
abusos das igrejas e dos sacerdotes, não só no plano dos costumes, como também no da especulação, à maneira do sucedido no Concílio de Trento, quando "escolásticos inventaram sutis e intrincados axiomas e teoremas" para tentar salvar Roma; a zombaria profana, que elimina a reverência pela religião; e "tempos de instrução, paz e prosperidade" porque se, em tempos adversos, os homens buscam conforto, apoio e esperança na religião, em tempos prósperos tendem a exaltar-se a si mesmos, com orgulho e arrogância.

O século, porém, parece muito mais propício a esse último tipo de causa e vê, ao lado das duas primeiras modalidades de ateus (os espirituais e os blasfemadores), o aparecimento de um terceiro grupo, ${ }^{5}$ os deístas, com a afirmação da religião natural, cuja razoabilidade dispensa a revelação e a graça. O século também vê as conseqüências do mecanicismo cartesio-hobbesiano e os efeitos do Teológico-Político, isto é, a difusão de um método exegético que instaura a dúvida quanto à autenticidade do Pentatêuco, que vincula entre profecia e política, milagre e superstição. É verdade que há deístas que não se limitam à filosofia natural mecanicista e julgam o cristianismo a forma superior da religião universal, a expressão mais alta da razoabilidade religiosa. Todavia, o aparecimento do deísmo, considerado efeito do naturalismo mecanicista, é responsável pela exigência de uma teoria da reta razão com a qual os cristãos defendem não só a razoabilidade do cristianismo, mas também atacam o ateísmo dos puros deístas.

Dessa maneira, um quadro teórico novo, que forçou a redefinição do campo teológico, também passou a exigir a ampliação do elenco das causas do ateísmo, outrora propostas por Bacon. Já não bastam causas externas, como as baconianas. É preciso, agora, determinar as causas intrínsecas do ateísmo como atitude teórica. ${ }^{6}$ Doravante, reconhece-se a diferença entre o ateu e o verdadeiro crente pelos argumentos apresentados para a prova da existência de Deus (origem, causa e finalidade do mundo criado), para a descrição e demonstração dos propósitos e das funções do universo e da existêncial conservação dos princípios da moralidade (teodicéia), e para a prova da autenticidade das Sagradas Escrituras e dos ensinamentos da Igreja (romana

5 Veja-se G. E. Aylmer "Unbelief in Seventeenth Century England”, in D. Pennigton e K. Thomas (orgs.) Puritans and Revolutionairies, Oxford, 1978.

6 A esse respeito cf. D. Wootton "Unbelief in Early Modern Europe", in D. Pennigton e K. Thomas (orgs.) Puritans and Revolutionairies, op. cit. Diferentemente de Febvre, Kolakowski e Aylmer, Wootton afirma a realidade do ateísmo ou da descrença como uma tradição que remonta à Idade Média, do lado letrado, com o averroísmo latino e o atomismo, além dos céticos acadêmicos e, do lado popular, com a descrença plebéia que, na Renascença, toma a feição do naturalismo do tipo daquele que aparece no "caso Menocchio", estudado por Carlo Guinzburg em O queijo e os vermes. 
ou reformada). São esses critérios que orientam a avaliação de Espinosa por Bayle:

Reconhecer um primeiro princípio e criador de todas as coisas não é prova de nãoateísmo(...) Estratão e alguns filósofos ateus, entre os antigos, e Espinosa, entre os modernos, reconhecem esse primeiro princípio. É preciso, portanto, para distinguirse do ateísmo, reconhecer formalmente que esse primeiro ser não age por emanação, nem produz o mundo por uma ação imanente, que ele não é determinado por uma necessidade natural, e que ouve nossas preces, podendo mudar o curso das coisas para atendê-las. ${ }^{7}$

Transcendência, criação ex nihilo, providência, intelecto, vontade, liberdade - do lado do ser de Deus -, livre-arbítrio, pecado original, fragilidade da razão e da vontade - do lado do homem -, socorro divino - por meio da graça, da revelação, do milagre e da religião -, eis o que afirma o crente autêntico e o que nega o verdadeiro ateu. $\mathrm{O}$ ateísmo tornou-se, portanto, especulativo, restando compreender como ele é possível e porque Espinosa é seu primeiro e mais significativo exemplar. Para Bayle, o racionalismo extremado de Espinosa, despojando Deus de intelecto e vontade, submetendo o homem à fatalidade das leis naturais e negando-lhe vontade livre, é, afinal, irracionalismo que torna impossível diferenciar os indivíduos segundo o critério moral da virtude e do vício.

Bayle observa que Espinosa "lançou-se no precipício" por haver enfrentado dificuldades reais a que não soube dar resposta adequada. Foi por tentar compreender, por um lado, como a matéria poderia ser eterna, diferente de Deus e não ser produzida do nada e, por outro lado, como um espírito infinito, soberanamente livre, criador de todas as coisas poderia produzir uma obra como o mundo, que Espinosa enfrentou questões que nem mesmo os crentes podem evitar. Afinal, uma matéria que exista necessariamente, mas seja destituída de atividade e submetida à potência de um outro princípio "é coisa com que a razão dificilmente se acomoda" e "a idéia de ordem combate tal associação". Não menos inconcebível é a idéia de uma matéria criada por um ato de vontade que faça existir o que antes não era. $\mathrm{O}$ antigo princípio "nada se faz a partir do nada" habita nossa imaginação e dificulta a idéia de criação ex nihilo. Difícil também, para nossa razão, a idéia de um ser infinitamente bom, justo e perfeito, que só poderia desejar criaturas boas, justas e felizes, mas permitiu que sejam criminosas e infelizes. Sofre a razão 
quando busca conciliar a idéia de liberdade humana e a qualidade de um ser tirado do nada, cujo acordo é condição para a existência de uma Providência livre, boa e justa.

Procurando evitar os inconvenientes dessas idéias, Espinosa escolheu o caminho da extravagância e da abominação. Todavia, se ele e o cristão são diferentes não é porque este último tenha encontrado as verdadeiras respostas àqueles problemas: simplesmente, encontrou soluções menos obscuras, menos opostas à luz natural e, sobretudo, capazes de consolá-lo nesta vida pela promessa de uma felicidade infinita, na outra.

Nessa perspectiva, não se pode pedir a quem refuta Espinosa que resolva os problemas por ele enfrentados, mas que esclareça porque os erros espinosistas são inaceitáveis. Trata-se de mostrar que as soluções de Espinosa acarretam dificuldades maiores do que as que ele pretendera resolver. Por isso Bayle centrará sua refutação na análise da proposição 5 e da Parte I da Ética.

\section{4. $O$ verbete Spinoza ou o ateísmo especulativo}

À primeira vista, o verbete Spinoza é desconcertante. De fato, o texto propriamente dito é breve, mas as notas marginais e as observações críticas são longas, ${ }^{8}$ parecendo interromper o raciocínio do texto central ao introduzir anedotas e informações dispensáveis ao desenvolvimento da argumentação. Todavia, a falta de unidade é aparente. Quando incorporamos notas e observações ao texto principal percebemos que o verbete é uma peça judiciária perfeitamente conforme à preceptiva retórica do século XVII. O motivo para o enorme levantamento de informações decorre de exigências próprias do gênero retórico escolhido para o verbete.

O verbete Spinoza inicia-se com concisão:

Espinosa (Bento). Judeu de nascença, depois desertor do judaísmo e, por fim, ateu, era de Amsterdã. Foi um ateu de sistema e com um método todo novo, embora o

8 Os verbetes do Dictionnaire organizam-se em três partes: um texto central sobre um autor ou um tema; notas marginais, indicadas com letras minúsculas, com referências e informações bibliográficas ou com correções e esclarecimentos sobre publicações, acontecimentos e pessoas; e, no rodapé, indicadas com letras maiúsculas, observações críticas, isto é, as opiniões políticas, religiosas e filosóficas de Bayle que esclarecem o que é dito no corpo do texto central. No caso do verbete Spinoza, o texto principal é curto, mas há 176 notas marginais e 27 observações críticas, algumas das quais mais longas do que o texto central. Essas observações, embora mescladas, podem ser agrupadas por assunto: $A, B, X$ afirmam que as teses espinosanas são antigas e existem em toda parte; C,G,H,U,Y,Z,AA trazem fatos e comentários relativos à biografia de Espinosa; $D, M, P, B B$ resumem e comentam brevemente as várias refutações do espinosismo já em curso; E,F,I,O,Q,R,S,T refutam as conseqüências morais do espinosismo; N,P,CC,DD trazem a refutação das teses metafísicas espinosistas. 
fundo de sua doutrina lhe fôsse comum com outros filósofos antigos e modernos, europeus e orientais. ${ }^{9}$

E no final do verbete, lê-se:

morreu bem persuadido de seu ateísmo. ${ }^{10}$

Como se observa, o exordium ou proemium apresenta o status causae: judeu de nascença, Espinosa passou do judaísmo ao ateísmo. Trata-se, portanto, do exame de um caso de ateísmo. A conclusio é uma verdadeira coda, pois resume numa frase a totalidade do percurso realizado: morreu bem persuadido de seu ateísmo. Torna-se, portanto, possível a condenação de sua filosofia.

A biografia de Espinosa opera em dois registros simultâneos: por um lado, confirma a teoria bayleana do papel do temperamento e do costume sobre o ateísmo, ou seja, a tese de que superstição ou falsa religião conduzem ao ateísmo e que o homem de bom temperamento pode ser um ateu virtuoso - nesse nível, a biografia opera como apresentação de signos e indícios sobre o acusado (temperamento, idade, riqueza, posição social, regra de vida, amigos, reputação); por outro lado, opera como escuta de testemunhas (quem o conheceu, quem sobre ele escreveu), cujo número deverá ser o maior possível (a credibilidade, como ensinam Cícero e Quintiliano, aumenta com o número de depoimentos) e cuja veracidade será tanto maior (também conforme lição de Cícero e Quintiliano) quanto menos estiverem diretamente interessadas no caso e mais interessadas na verdade dos fatos. Em outras palavras, Bayle apresenta os indícios e sinais do ethos do acusado e o seu próprio ethos como acusador justo e imparcial.

A aparente miscelânea de textos sobre Espinosa, tanto a favor como contra ele, e de referências a inúmeras obras de pensadores orientais e europeus antigos, medievais e modernos também faz parte dos signos e indícios, porém não estão apenas a serviço da coleta de testemunhos, mas servem para instruir o processo para a produção da causa, particularmente quando recolhidos pela comparação entre as idéias do acusado e de outros pensadores, já submetidos ao julgamento de impiedade e incredulidade.

Após ouvir as testemunhas, recolher signos e indícios, selecionar as primeiras e classificar os segundos, ou seja, após a inventio, Bayle examina as

9 Bayle, Dictionnaire Historique et Critique de Mr. Pierre Bayle, 2a. edição, Roterdã, 1703, p.610. Usamos esta edição porque contém novos dados e comentários acrescentados por Bayle ao verbete da primeira edição, de 1697.

10 Idem ibidem, p. 624. 
provas diretas. Passa, então, à narratio, isto é, ao exame dos textos de Espinosa para avaliar os danos por eles causados (a Deus e aos homens). De acordo com a preceptiva retórica de amplificação da prova, é apontada a semelhança de seus escritos com os textos de outros autores julgados ateus.

Instruído o processo, tanto de verba quanto de re, estabelecido o caso e definida a causa, Bayle, de posse da evidência segura, encaminha o processo ao tribunal da recta ratio para que todo "espírito reto" e todo "homem de bem" não possam, sem justo motivo, recusar o veredito que lhes é ensinado pela argumentação do acusador.

a) inventio ou determinação da causa ou do caso

A partir dos dados biográficos, Bayle descreve Espinosa como homem "que não aceitava coação sobre a consciência e era grande inimigo da dissimulação", motivo pelo qual, ao romper com os rabinos, se afasta da Sinagoga para evitar hipocrisia, ainda que, segundo o autor, isso the houvesse sido proposto por alguns dirigentes da comunidade judaica de Amsterdã. Embora bem acolhido nos meios cristãos dissidentes, Espinosa teria preferido o isolamento porque, ao ler Descartes e ser "tomado por forte paixão pela busca da verdade", teria abandonado todo o resto para dedicar-se à filosofia. Apesar da vida solitária, sua reputação como fabricador de lentes e filósofo espalhou-se rapidamente, e "de toda parte, acorriam os espíritos fortes" para ouvi-lo e com ele discutir. Pessoa afável, honesta, prestativa e "de costumes bem regrados", Espinosa suscita o comentário de Bayle: "é estranho". Mas nem tanto, prossegue o verbete. Porque espantar-se com que um ateu seja virtuoso quando se vê "os que vivem muito mal, embora persuadidos do Evangelho"? Estranho não é isso. A pergunta de Bayle é outra: porque Espinosa "se teria precipitado no ateísmo"? A resposta não se faz esperar: porque exagerou as idéias de Descartes. Bayle reafirma um dos mais persistentes lugares comuns do século, isto é, que o cartesianismo mal compreendido é germe do ateísmo. Está determinada a causa e definido o caso. Resta circunscrevê-los.

\section{b) narratio: exposição e refutação do espinosismo}

Dispondo-se a realizar a tarefa que, em sua opinião, ainda não fora levada a cabo por ninguém, ou seja, a refutação definitiva do espinosismo, "a mais monstruosa hipótese que se possa imaginar", Bayle, apoiado nas testemunhas, afirma que "por modéstia" Espinosa recusara dar seu nome a uma seita e que poucos são seus seguidores. Entre estes, não são muitos os que estudaram a obra e, destes, raros os que a compreenderam, "desencorajados pelas perplexidades e abstrações" que a caracterizam. Com isso, Bayle afasta o temor generalizado 
de que o espinosismo pudesse ter-se espalhado e contaminado toda a Europa, atribuindo sua pequena presença à obscuridade da própria doutrina. Assim procedendo, o refutador delimita seu campo de ação: o processo não visa aos poucos espinosistas existentes, mas à obra de Espinosa. Com relação a esta, ainda que seguidores e críticos fiquem embaraçados com sua obscuridade, no que tange ao ateísmo, a doutrina de Espinosa não engana a ninguém. A acusação é uma só e uma só deverá ser a refutação: o caso a julgar é um processo de ateísmo. Finalmente, embora as idéias espinosistas sejam "as mais diametralmente opostas às noções mais evidentes de nosso espírito", a refutação do espinosismo não pode cair na armadilha dele nem ceder a ele. Cabe ao refutador enunciar claramente as principais teses de Espinosa para melhor combatê-las. Através do exame e comentário dos textos, Bayle pretende pôr em pratica, mais do nunca, a regra da boa-fé crítica, exposta no verbete Barlette: "não se pode confundir o que um homem diz com as conseqüências do que disse", portanto, "acusai as pessoas de haverem dito exatamente o que disseram."

A doutrina de Espinosa resume-se a poucas teses: há, na Natureza, uma única substância, dotada de infinitos atributos, entre os quais a extensão e o pensamento; todos os corpos existentes na Natureza são modificações dessa única substância, enquanto extensa, e todas as almas dos homens são modificações dessa mesma substância, enquanto pensante; essa única substância é Deus, o ser necessário e infinito, que produz em si mesmo e por uma ação imanente tudo o que existe, isto é, as criaturas são suas modificações.

Todavia, prossegue Bayle, "son sentiment n'est pas nouveau”. Por inserirse na longa tradição atéia, o espinosismo não faz senão retomar uma "seita conhecida dos chineses", opiniões de "certos maometanos conhecidos como homens da verdade", a "cabala dos sufis", idéias de alguns "letrados persas", certos "dogmas conhecidos dos indus", o hermetismo dos egípcios, também defendido por Fludd, mas, felizmente, refutado por Gassendi, a posição dos saduceus maometanos, para os quais "tudo o que se vê, tudo o que está no mundo, tudo o que foi criado é Deus", e as idéias da seita chinesa de Foe Kiao (descrita pelos missionários jesuítas). Com variantes, as doutrinas orientais resumem-se a três afirmações: identidade entre Deus e o mundo, irrealidade dos indivíduos, meras aparências na superfície da matéria, e recusa da imortalidade individual da alma, com a conseqüente recusa de uma Providência divina que julga os homens segundo o bem e o mal definidos por Sua lei. A este orientalismo devem-se acrescentar a Cabala judaica, o averroísmo maometano, a lista dos hereges cristãos, adeptos da idéia de uma Alma do Mundo, isto é, os neoplatônicos de várias tonalidades e, evidentemente, Abelardo, "acusado 
de haver dito que todas as coisas estavam em Deus e que Deus era todas as coisas".

Dessas doutrinas antigas, como das cinzas, nasce o espinosismo cujas teses, insiste Bayle, não são novas. Nova é a sistematização que recebem de Espinosa e é essa novidade que precisa ser examinada, se se quiser refutá-lo. Em outras palavras, os que até agora refutaram o espinosismo incorreram sempre no mesmo erro porque meramente opuseram outras idéias às de Espinosa, sem perceber que esse procedimento o fortalece, em vez de enfraquecê-lo. A boa refutação precisa realizar duas operações: na primeira, demonstrar que Espinosa ignora o verdadeiro sentido dos conceitos que emprega; na segunda, voltar contra o espinosismo as conseqüências absurdas de suas próprias teses.

Admitamos que haja no universo uma única substância infinita, extensa e pensante, idêntica à Natureza e a todos os entes nela existentes. Se isso for admitido, então ninguém menos do que os espinosistas poderá negar a aparição de espíritos - que Espinosa nega -, nem a existência dos milagres - que Espinosa recusa - nem o medo do inferno - que Espinosa não aceita.

Com efeito, quando se crê que o mundo foi criado do nada pela vontade de um ser soberanamente perfeito, pode-se negar a existência de anjos, dizendo-se que agradou a Deus criar apenas as almas dos homens e não Lhe aprouve criar outros espíritos. Entretanto, quando se supõe que o criador não agiu livremente, que estendeu necessariamente toda sua potência, que seu pensamento está modificado pelo universo inteiro e que, pelo dualismo dos atributos divinos, não há qualquer "vínculo natural entre o cérebro e o entendimento", então não há qualquer razão que impeça a existência de anjos, espíritos e espectros. Do mesmo modo, nada justifica que Espinosa negue a realização de milagres. Quando os espinosistas os recusam, afirmando que Deus e a Natureza são idênticos, que Deus jamais suspende a racionalidade da ordem natural, porque nada faz contra as leis que exprimem sua potência necessária, não sabem o que dizem. De fato, se a potência e o entendimento divinos são infinitos e estão espalhados pelo universo inteiro, então, nada impede que alguns modos de Deus conheçam, tal como Deus a conhece, a estrutura invisível das menores porções dos corpos e que possam alterá-la segundo leis naturais. Neste caso, podem, por exemplo, ressuscitar um morto, como Jesus Cristo ressuscitou Lázaro. Incoerência semelhante encontra-se na negação do medo do inferno. Mesmo que não se admita a existência do ser soberamente perfeito, criador do universo, que o governa e remunera os homens segundo seus méritos, ainda assim, será preciso admitir que a infinitude divina, extensa e pensante, espalha-se pelo universo inteiro e não se reduz ao pequeno ponto chamado 
Terra. Neste caso, é preciso admitir que, nos espaços imensos e invisíveis, existem modificações divinas, em tudo semelhantes às terrestres: "a razão, o espírito, a ambição, o ódio, a crueldade estariam apenas na terra e não em toda outra parte?". É preciso também reconhecer que essas modificações podem julgar, como o fazem os homens, que têm poder sobre tudo quanto possam dominar e que, embora não as vejamos nem as conheçamos, podem ser mais fortes do que nós e não ser indiferentes a nós, tendo força para nos dominar. Além disso, nossas almas, porque são modificações do pensamento de Deus, são imortais, mesmo que Espinosa, incoerente e contraditoriamente, o negue. Nada impede, portanto, que após a morte, nossa alma se dirija a esses espaços imensos, onde modificações divinas poderosas a castiguem ou recompensem.

No entanto, essas refutações são insuficientes para abalar a obstinação espinosista. É preciso atingir a doutrina em seu centro nervoso e por isso o núcleo da crítica de Bayle é a unicidade substancial e sua conseqüência, a identidade entre Deus e Natureza, que destrói o ser divino e desordena os seres naturais. "Prendi-me à refutação da proposição que é a base de seu sistema", afirma Bayle, referindo-se à proposição 5 da Parte I da Ética: "Na Natureza não pode haver várias substâncias de mesma natureza ou atributo". E exclama: "Eis seu calcanhar de Aquiles!".

Além de considerar inadmissível a existência de uma única substância, colocada por Espinosa no lugar da necessária multiplicidade substancial, garantidora da individualidade dos entes, Bayle também considera inadmissível que a extensão possa ser um atributo da substância divina, pois a divisibilidade e a corruptibilidade, próprias da matéria, são incompatíveis com a essência una e incorruptível de Deus, e julga ainda mais inaceitável que tal atributo divino se modifique em corpos finitos. Todavia, a tese do atributo extensão não é apenas incompatível com o ser de Deus: ela também o é com relação às criaturas. De fato, a continuidade e a indivisibilidade, próprias de um atributo divino, fazem com que a extensão espinosista proíba a existência real de seres individuais, de sorte que os corpos finitos reduzem-se a meras aparências ou à inexistência. Em suma, a divisão e corrupção da matéria, de um lado, e a indivisão, simplicidade e continuidade do ser divino, de outro, revelam o absurdo de afirmar que há uma única substância e que Deus é extenso.

No entanto, as críticas ao conceito espinosano de extensão, cujos enganos Bayle remete a erros científicos do filósofo e à sua ignorância das novas experiências da filosofia natural, erros e ignorância decorrentes de pressupostos metafísicos absurdos, são menos severas do que aquelas endereçadas à imanência do atributo pensamento, isto é, contra a demonstração de que as almas são modificações finitas do intelecto infinito, ou nas palavras de Bayle, 
que todos os sentimentos de todos os homens estejam em uma só cabeça. ${ }^{11}$

Interpretando a causalidade imanente da substância como identidade entre Deus e os modos finitos (humanos, animais, vegetais e minerais), e a do atributo pensamento como identidade entre um sujeito (Deus) e todos os conteúdos das mentes humanas, Bayle é taxativo:

Iremos ver absurdos ainda mais monstruosos ao considerarmos o Deus de Espinosa como sujeito de todas as modificações do pensamento (...) Se é prodigioso absurdo, falando do ponto de vista físico, que um simples e único ser seja modificado ao mesmo tempo pelos pensamentos de todos os homens, é abominação execrável, quando considerado do ponto de vista da moral. Como? Então o ser infinito, o ser necessário, o ser soberanamente perfeito não será firme, constante e imutável? Que digo? Imutável? Não será por um só momento o mesmo, seus pensamentos se sucederão uns aos outros infindável e incessantemente. ${ }^{12}$

Contudo, prossegue Bayle, muito pior nos aguarda, pois a mobilidade e inconstância infinitas farão com que

para cada bom pensamento, o ser infinito tenha mil outros tolos, extravagantes, impuros, abomináveis. Produzirá em si todas as loucuras, todos os devaneios, todas as imundícies do gênero humano; será não só causa eficiente deles, mas também seu paciente; alegrar-se-á com eles pela mais íntima união que se possa conceber, pois é uma união penetrativa, ou melhor, uma verdadeira identidade, uma vez que o modo não é realmente distinto da substância modificada. ${ }^{13}$

Muitos grandes filósofos, continua o verbete, não podendo compreender que seja compatível com o ser soberano suportar que o homem seja tão malvado, foram levados à posição de Maniqueu, que supôs a existência de dois princípios, um bom e outro mau.

Ora, eis aqui um filósofo que acha muito bom que o próprio Deus seja agente e paciente de todos os crimes e de todas as misérias do homem. ${ }^{14}$

Com Espinosa, portanto, não só a essência divina foi conspurcada pela mutabilidade, também o poder divino foi aniquilado, pois tornou-se causa eficiente e paciente das imundícies, das misérias e dos crimes humanos. A perfeição e a onipotência divinas foram reduzidas a nada. 
Deus, o ser necessário e infinitamente perfeito, é bem a causa de todas as coisas que existem, mas não difere delas. Não há senão um ser e uma natureza e esta natureza produz nela mesma e por uma ação imanente tudo o que ele chama de criaturas. Deus é, conjuntamente, agente e paciente, causa eficiente e sujeito e nada produz que não seja Sua modificação. Eis aí uma hipótese que ultrapassa toda extravagância que se possa proferir. O que os poetas pagãos ousaram cantar de mais infame contra Júpiter e contra Vênus não chega perto da idéia horrível que Espinosa nos dá de Deus, pois os poetas, pelo menos, não atribuíam aos deuses todos os crimes que se cometem nem todas as fraquezas do mundo, mas, segundo Espinosa, não há outro agente nem outro paciente senão Deus com relação a tudo o que chamamos de mal de pena e mal de culpa, mal físico e mal moral. ${ }^{15}$

Bayle não se admira de que haja conflitos entre os homens. Pelo contrário, sendo indivíduos substancialmente distintos, são movidos por paixões e interesses contrários Porque distinguem entre o "meu" e o "teu", podem odiarse uns aos outros, matar-se uns aos outros e até mesmo, como já se ouviu contar, é compreensível que os vencedores devorem os vencidos,

mas que, sendo os homens modificações do mesmo ser e havendo apenas Deus como agente, e que o mesmo Deus, numericamente, modificando-se em turco e modificando-se em húngaro, haja guerras e batalhas, já ultrapassa todos os monstros, todos os desregramentos quiméricos das cabeças mais loucas que já foram lançadas no hospício. ${ }^{16}$

Seguindo os preceitos retóricos barrocos da elocutio como conjunto bem ordenado de topos e tropos, a argumentação de Bayle obedece a uma gradação precisa ao passar do "prodigioso absurdo" - do ponto de vista físico - à "abominação execrável" - do ponto de vista moral. No primeiro caso, pode-se opor às teses espinosistas argumentos racionais, bastando demonstrar a contradição da unicidade substancial, pois "há no universo tantas substâncias quanto sujeitos" o que, evidentemente, significa "que não podem receber ao mesmo tempo as mesmas denominações". No segundo caso, entretanto, trata-se de demonstrar que as idéias espinosistas são perniciosas porque abomináveis, pois, com elas, inconstância, falta de firmeza e mutabilidade são atribuídas a Deus. Muito mais: imundícies, misérias e crimes definem a ação da divindade. Pior: Deus é paciente das mais terríveis paixões, dilacerado internamente e alegre com seu dilaceramento. Eis aí um pensamento "infinitamente mais ridículo do que o Proteu e o Dionísio dos poetas". 
Todavia, a argumentação prossegue num crescendo quando Bayle retira a principal conseqüência da imanência, isto é, de um Deus internamente dividido e disperso que é, simultaneamente, agente e paciente de sua própria causalidade: do absurdo quanto à essência divina, passamos à abominação quanto à sua potência. Atingindo o núcleo da divindade, ou seja, seu poder como intelecto e vontade soberanos, Espinosa "é o único que reduz a divindade à miséria" e ultrapassa monstros e desregramentos quiméricos das "cabeças mais loucas". Está além da loucura conhecida.

E assim, todas as frases com que exprimimos o que os homens fazem uns contra os outros só terão sentido quando reduzidas às seguintes: 'Deus odeia a si mesmo, suplica graças a si mesmo, mata-se a si mesmo, calunia-se a si mesmo, envia-se a si mesmo ao cadafalso, etc.'(...) Um bom espírito preferiria arranhar a terra com unhas e dentes a ter que cultivar hipótese tão absurda. ${ }^{17}$

A insanidade de Espinosa é patente, pois é visível que seu sistema destrói a coerência da linguagem e o sentido das idéias, e que, com ele, o pensamento se torna rigorosamente impensável. A imprecisão de vocabulário, a imperícia demonstrativa e o descuido conceitual simplesmente comprovam o grau de extrema alienação do filósofo.

Todavia, é no passo seguinte que a argumentação de Bayle alcança o clímax, quando a elocutio classifica as idéias espinosistas de "infames e furiosas extravagâncias", porque, agora, provará que Espinosa não é simplesmente insano, mas louco furioso, e sua filosofia, "uma hipótese que ultrapassa toda extravagância que se possa imaginar".

Seguindo (sem mencioná-la explicitamente) a lição de Cícero ${ }^{18}$ e do Direito Romano, o século XVII opera com três sentidos da loucura: o jurídico (estar alienus juris), o médico (a insania) e o noético (a dementia). Reconhece, também por essa lição, que o insano cuja razão "caiu" temporariamente encontra-se no estado de dementia. Em contrapartida, segundo a mesma lição, o insano furioso é aquele que perdeu definitivamente a razão; não está demente, mas é demente. Essa lição, tacitamente pressuposta e nunca explicitada por Bayle, é o núcleo de sua nova argumentação.

Bayle sabe que infâmia e furor não pertencem ao mesmo campo semântico. A primeira pertence ao contexto jurídico na qualidade de crime e, visto tratar-se aqui de crime contra Deus, penetra também no campo teológico, equivalendo à blasfêmia. Graças a esse deslizamento semântico, Bayle arrasta o crime de 
infâmia para o interior do campo religioso e pode reuni-lo ao furor. Este, ainda que juridicamente definido pela condição daquele que se encontra alienus juris, pertence mais propriamente ao contexto médico que, no século XVII, o define como melancolia e mania, delírio não febril, embora ardente, feito de violência e audácia, resultante de uma falha dos sentidos e da imaginação, e do esgotamento dos humores, com ressecamento das fibras cerebrais. Todavia, desde o hermetismo renascentista, o furor recuperara o antigo sentido teológico da manía grega como divinus furor ou entusiasmo e, com este sentido, retornou ao campo religioso quando Calvino se lançou contra os libertinos espirituais para chamá-los de entusiastas e por isso mesmo ateus. Ao tomar a infâmia como blasfêmia e o furor como doença religiosa, Bayle pode reunir os dois termos. Essa reunião é assegurada pelo uso do termo extravagância. De fato, ao insistir na extravagância de Espinosa, Bayle dispõe de uma teoria que já reuniu os sentidos médico, jurídico e religioso daquilo que, na linguagem do século XVII, significa um determinado tipo de loucura, aquela que Robert Burton, em Anatomy of Melancholy, designa como "melancolia religiosa", doença da alma própria dos epicuristas, hereges, libertinos e ateus, isto é, de todos aqueles que "imaginam toda a realidade explicável apenas por causas naturais". Espinosa, ultrapassando todas as extravagâncias, vai além do simples naturalismo e sua insanidade é absoluta. Se, portanto, no primeiro movimento argumentativo, Bayle conseguira reunir a infâmia ao furor, fazendo a primeira deslizar para o interior do campo teológico, agora, fazendo o significado médico e jurídico do furor também deslizar para o interior do campo teológico, pode reuni-lo à infâmia e apresentar um único crime.

Também é lição de Cícero nas Tusculanas que o furor atinge não só a vontade, mas ainda o espírito do sábio, afeta sua razão e desordena seu entendimento. Por isso, ensina Bayle seguindo implicitamente a lição ciceroniana, o Deus de Espinosa, imundo, inconstante, criminoso, miserável, com pensamentos extravagantes e tolos, "produzirá em si todos os devaneios, todas as loucuras". Tamanho delírio suscita o diagnóstico inapelável: a ruína de Deus, habitado por pensamentos extravagantes e tolos, não é senão loucura de Espinosa, cujas idéias são "infames, furiosas, e monstruosas".

Bayle não escolhe por acaso a idéia de tolice, mas, com ela, remete deliberada e silenciosamente ao que todo mundo, no século XVII, sabe. Com efeito, tendo pensamentos tolos, o Deus de Espinosa é o único e verdadeiro ateu, pois, está nas Escrituras que "o tolo diz em seu coração: não há Deus". Pensando tolamente, isto é, sem razão, não admira que seja ignorante, hipócrita e suicida, mate e devore a si mesmo, negue a justiça e Sua própria existência. Eis porque seus tolos pensamentos só poderão ser extravagantes. 
De fato, nas Tusculanas, Cícero observa que furioso é aquele que se encontra fora de si, destituído de seus poderes - ex sua potestate -, motivo pelo qual as Doze Tábuas lhe vedam o direito de dispor de seus bens. Ao falar em "furiosas extravagâncias", Bayle há de ter em mente a assimilação, feita por Descartes, entre extravagant e demens. ${ }^{19}$ Com o emprego do termo "extravagante", o verbete atinge dois alvos: Espinosa teria feito do legislador e juiz supremo um ser juridicamente desqualificado; porém, teria feito muito mais, pois o Direito Romano define a pessoa como sujeito capaz de direitos e o Deus espinosano está despojado de personalitas, jus e potestas. Tendo sido destituído de sua mais alta prerrogativa e de seu supremo direito - a soberania universal -, não causa espanto que o Deus de Espinosa tenha pensamentos impuros e abomináveis. Tornou-se um pobre diabo.

A indivisão entre Deus e a Natureza, ou a unicidade substancial, é monstruosidade, portanto, contra-natureza e contrária à razão. Esta exige separação entre Criador e criaturas, exige também que a causalidade eficiente divina seja transitiva e eminente, que a reunião entre Deus e os entes finitos provenha da causalidade final, por ensinar que o intelecto e a vontade de Deus desejaram as coisas criadas sub ratione boni. A causalidade eficiente imanente e a recusa da causalidade final, aliadas à negação de que a essência de Deus comporte intelecto e vontade, redundam no Deus sive Natura, no qual um Deus, tolo e extravagante, tornou-se abismo da irrazão. Nesse discurso desvairado, as repartições feitas pelo bom senso estão embaralhadas e a recta ratio, destruída. As teses de Espinosa são "frívolas e cavilosas”, marcadas com aquela fatuidade que os médicos apontam como primeiro indício de loucura.

\section{c) conclusio: condenação e coda}

A unicidade substancial pede, portanto, duas condenações. A primeira, intelectual, pois as idéias claras e distintas de substância e modo tornam logicamente impossível a coexistência, numa mesma substância, de modificações que se excluem reciprocamente. A segunda, moral, visto que a existência simultânea ou sucessiva de modos opostos no interior de Deus, isto é, as contradições entre pensamentos, volições e afetos dos homens, arruína a perfeição divina e a divina justiça, que não poderá julgar os homens segundo o bom e o mau.

19 "Termo jurídico que designa toda categoria de gente incapaz de atos religiosos, civis e judiciários; os dementes não dispõem da totalidade de direitos quando se trata de falar, prometer, contratar, assinar ou intentar uma ação, etc", M. Foucault "Mon Corps, ce Papier, ce feu”, Appendice II, Histoire de la Folie à l'Age Classique, 2a. edição, p. 590 
A melhor refutação do espinosismo, afirma Bayle, é, portanto, essa que, após redefinir corretamente as idéias mais claras e evidentes do espírito humano e localizar na história das disputas filosófico-teológicas quando foram obscurecidas, demonstra que o pensamento de Espinosa é incapaz de operar com tais conceitos, e sobretudo, mostra suas conseqüências, pondo-o em contradição consigo mesmo. Pela via da clareza conceitual e da prova da incoerência interna, refuta-se facilmente a doutrina espinosista. Assim, o filósofo fatalista, que negara a Providência de Deus, desta recebe o merecido castigo:

Dir-se-ia que a Divina Providência puniu de maneira particular a audácia desse autor, cegando-o de tal modo que, para fugir das dificuldades que podem magoar um filósofo, ele se lançou em embaraços mais inexplicáveis e tão patentes que qualquer espírito reto será capaz de reconhecer. ${ }^{20}$

Bayle pode, então, pronunciar o veredito que será aceito por todo homem de bem: Espinosa é confuso porque incoerente; incoerente porque extravagante; extravagante porque louco furioso. A esse veredito vem juntar-se a sentença: a filosofia de Espinosa é inútil.

De fato, apliquemos a ela seus próprios princípios: se somos modificações de Deus, se Deus é Natureza, se nesta tudo segue leis necessárias ou fatais, então Espinosa não teve liberdade para escrever o que escreveu, não só porque não foi livre (seja porque nada há livre na Natureza, seja porque, sendo louco, não é sujeito de direitos), mas também porque

se uma verdade ou um dogma tiverem que ser estabelecidos, a Natureza o fará por mim em minha obra e, se não puderem ser estabelecidos, então, de nada servirão meus escritos. ${ }^{21}$

Aplicando à doutrina espinosista o "argumento preguiçoso", isto é, a conseqüência lógica do fatalismo, Bayle pode afirmar que basta voltar contra Espinosa sua própria concepção de Natureza para que a inutilidade de suas idéias se evidencie e o silencio se imponha: fosse ele coerente em sua fúria, nada teria escrito. Aparentemente inatacável e irrefutável quando lido com as lentes de Espinosa, o espinosismo revela toda sua vulnerabilidade quando interpretado por espíritos retos. Torna-se inofensivo e pode ser ignorado. A esse veredito vem juntar-se a confirmação trazida por uma prova suplementar: 
Concluo dizendo que várias pessoas me asseguraram que sua doutrina, considerada independentemente dos interesses da religião, pareceu bastante desprezível aos maiores matemáticos de nosso tempo (falaram-me, entre outros, dos senhores Huyghens, Leibniz, Newton, Bernouilli, Fatio). Nisso pode-se crer facilmente, desde que se considerem, em primeiro lugar, que ninguém está mais persuadido da multiplicidade das substâncias do que aqueles que estudam a extensão e, em segundo lugar, que a maioria desses senhores admite a existência do vácuo. Ora, nada mais oposto à hipótese de Espinosa do que isso. ${ }^{22}$

Dessa maneira, a peça judiciária se desloca de seu centro acusador para quase inocentar Espinosa, graças ao diagnóstico de insanidade permanente, que inutiliza sua obra e explica a fraqueza do more geometrico. 